\title{
KONTRIBUSI RELIGIUSITAS DALAM RASIONALITAS KONSUMSI RUMAH TANGGA MUSLIM
}

\author{
Anton Bawono \\ Sekolah Tinggi Agama Islam Negeri (STAIN) Salatiga \\ Alfatbbawono@yaboo.co.id
}

\begin{abstract}
The purpose of this study was to determine whether a Muslim in belonged to excessive consume or are still proportional. This study uses the entire bousehold population of Muslims who already live independently in the province of Daerah Istimewa Yogyakarta. While the sample used by 109 respondents. Methods of analysis by looking at the value of average propensity to consume (APC), if the value of the $A P C>1$, this illustrates that the Muslim isrof consumption or excessive, and otherwise it is called a proportional or rational. The analysis showed that the consumption behavior of Muslims households a sample of this with the APC rate is less than 1, while the scoring level of religiosity respondents using a scale of $0-10$ depicts the average respondent is in a position high enough level of religiosity. Based on the findings in this study, it can be concluded that the level of consumption of a Muslim is still rational and not excessive. One cause of consumption rationality of a Muslim is the level of religiosity, so that consumption is not excessive.
\end{abstract}

Keywords: Rationality, Isrof, Religiosity

\begin{abstract}
Abstrak
Tujuan dari penelitian ini adalab untuk mengetabui apakah seorang muslim dalam berkonsumsi termasuk dalam golongan yang berlebiban ataukah yang masib proporsional. Penelitian ini menggunakan populasi selurub rumah tangga muslim yang sudab bidup mandiri di wilayah propinsi Daerah Istimewa Yogyakarta. Sedangkan sampel yang digunakan sebesar 109 responden. Metode analisis dengan melihat nilai average propensity to consume (APC), jika nilai $A P C>1$, ini menggambarkan babwa konsumsi seorang muslim itu isrof atau berlebiban, dan jika sebaliknya maka disebut masib proporsional atau rasional. Hasil analisis menunjukkan bahwa perilaku konsumsi rumah tangga muslim yang menjadi sampel penelitian ini dengan angka APC yang kurang dari 1, sedangkan jika dilihat dari skoring tingkat religiusitas responden dengan menggunakan skala $0-10$ menggambarkan rata-rata responden berada pada posisi tingkat religiusitasnya cukup tinggi. Berdasarkan temuan dalam penelitian ini, maka dapat disimpulkan babwa tingkat konsumsi seorang muslim masib tergolong rasional dan tidak berlebihan. Salah satu penyebab rasionalitasnya konsumsi seorang muslim adalah tingkat religiusitas, sebingga konsumsinya tidak berlebihan.
\end{abstract}

Kata Kunci: Rasionalitas, Isrof, Religiusitas 


\section{Pendahuluan}

Arus globalisasi telah sangat terasa dampaknya terhadap sendi-sendi kehidupan ekonomi baik pada rumah tangga maupun bangsa Indonesia. Tidak sedikit pula, arus globalisasi yang semakin mengglobal ini menghanyutkan mimpi-mimpi rumah tangga untuk hidup sederhana dan dapat menikmati hari tua dengan tanpa tekanan ekonomi. Munculnya iklan baik di media cetak maupun elektronik, telah ikut andil dalam propaganda perilaku hedonis. Hedonisme adalah pandangan hidup yang menganggap bahwa orang akan menjadi bahagia dengan mencari kebahagiaan sebanyak mungkin dan sedapat mungkin menghindari perasaan-perasaan yang menyakitkan (Franz Magnis, 1987: 114). Hedonisme merupakan ajaran atau pandangan bahwa kesenangan atau kenikmatan merupakan tujuan hidup dan tindakan manusia (Lorens Bagus, 282: 2000). Untuk mengejar kesenangan hidup tersebut, menyebabkan beberapa rumah tangga berperilaku konsumsi yang berlebihan.

Islam sendiri melarang umatnya untuk hidup secara berlebihan, tetapi Islam mengajarkan untuk hidup secara proporsional. Gaya hidup yang hedonis yang kemudian membawa pada perilaku yang konsumtif tentu akan merugikan diri sendiri dan orang lain. Perilaku yang konsumtif akan membawa pada kondisi konsumsi berlebihan yaitu konsumsi yang melebihi batas kemampuan keuangan (pendapatan) yang dimiliki sekarang. Perilaku tersebut biasanya berdampak pada hutang, yang bebannya akan ditanggung dikemudian hari. Hal ini akan berimplikasi pada semakin sedikitnya tabungan yang akan dapat dihimpun rumah tangga tersebut. Secara nasional akan berdampak pada semakin naiknya permintaan agregat yang berdampak pula pada naiknya tingkat inflasi.

Naiknya tingkat inflasi, pemicu diantaranya adalah pola konsumsi yang berlebihan, yang biasanya dilakukan oleh golongan yang berlebih dana. Perilaku ini yang berdampak pada semakin menderitanya si miskin, karena si miskin akan semakin tidak dapat menjangkau barang-barang yang harganya naik tersebut yang merupakan barang kebutuhan hidupnya juga. Dari kejadian inilah maka ada sebuah keharusan bagi si kaya memberikan sebagian rejekinya kepada si miskin baik yang meminta maupun yang tidak 
meminta, hal ini dipertegas dalam QS. Adz Dzariyaat, ayat: 19;

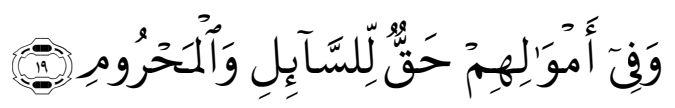

"dan pada harta-harta mereka ada hak untuk orang miskin yang meminta dan orang miskin yang tidak mendapat bagian".

Ayat tersebut di atas menggambarkan rasionalitas seorang muslim dalam berkonsumsi harus proporsional dan memperhatikan hak orang lain supaya tercipta kondisi yang tidak menimbulkan banyak kesenjangan antara si kaya dan si miskin. Secara makro akan menciptakan kestabilan ekonomi yaitu dengan terredamnya laju inflasi dengan tidak berlebihannya rumah tangga dalam berkonsumsi. Kondisi ini tercipta jika setiap rumah tangga dapat mengamalkan ajaran agamanya dengan baik. Kemampuan mengamalkan ajaran agama dapat dilihat dari tingkat religiusitasnya.

Religiusitas dapat sebagai pengendali perilaku konsumsi rumah tangga. Dengan semakin hingar bingarnya gaya hidup yang di picu oleh pergaulan, juga media iklan baik di media cetak maupun elektronik, di samping kesempatan kredit yang longgar, membuat rumah tangga dapat terhanyut dalam hiruk pikuk kehidupan hedonis yang konsumtif. Kehidupan konsumtif dapat berimplikasi negatif, yang dapat membuat sebuah rumah tangga menjadi tidak rasional. Rasionalitas'seorang muslim dipengaruhi oleh tingkat religiusitas, religiusitas inilah yang akan diharapkan sebagai pengendali perilaku yang konsumtif. Sehingga dalam penelitian ini yang menjadi tujuan penelitian adalah membuktikan apakah perilaku rumah tangga muslim itu rasional, dan apakah perilaku rumah tangga muslim yang rasional tersebut juga memiliki tingkat religiusitas yang tinggi pula.

\section{Konsumsi Hedonis}

Kapitalisme baru, dibangun melalui pemasaran massal, kenaikan standar hidup dan ekspansi hutang dan kredit, menghancurkan kemampuan untuk menunda kepuasan dan menggantikannya dengan hedonisme (Nick Stevenson, 2002: 307). Hedonisme $\square$ adalah pandangan hidup yang menganggap bahwa orang akan menjadi 
bahagia dengan mencari kebahagiaan sebanyak mungkin dan sedapat mungkin menghindari perasaan-perasaan yang menyakitkan (Franz Magnis, 1987: 114). Hedonisme merupakan ajaran atau pandangan bahwa kesenangan atau kenikmatan merupakan tujuan hidup dan tindakan manusia (Lorens Bagus: 2000: 282). Untuk mengejar kesenangan hidup tersebut, menyebabkan beberapa rumah tangga berperilaku konsumsi yang berlebihan.

Perilaku konsumsi tiap individu memiliki banyak variasi: pengeluarannya ada yang berlebihan, ada yang proporsional dan ada pula yang sangat irit sekali. Perilaku konsumsi tersebut biasanya mengikuti gaya hidup dan prinsip yang dipegang masing-masing. Di era yang kian modern ini, arus globalisasi semakin mengglobal yang ditunjukkan antara lain dengan semakin banyaknya tawaran produsen akan barang-barang konsumsi baik dari dalam negeri maupun manca negara yang ditawarkan di media masa (Peter Stearns, 2001). Jenis barang konsumsi tertentu sering kali oleh sebagian kalangan sebagai ukuran kelas sosial bagi penggunanya. Sebagian kalangan juga mengatakan bahwa semakin mahal suatu produk akan dipandang semakin berkelas bagi orang yang mengkonsumsinya. Beberapa individu merasa senang dan bangga jika dianggap berkelas, kondisi ini yang menyebabkan beberapa individu terjebak dalam berkonsumsinya. Hal ini sebagian besar disebabkan karena perilaku konsumsinya melebihi pendapatan yang dia miliki saat ini. Akan tetapi perilaku ini akan semakin mendorong banyak industri untuk berkembang. Hal ini seperti yang disampaikan oleh Sandy Lutz (2008: 83), bahwa ketika konsumen membayar lebih dari pendapatannya, mereka membuat pilihan yang lebih baik, dan ini dapat memiliki pengaruh besar bagi industri.

Perilaku konsumsi dengan tujuan mengejar gaya hidup, biasanya di dalam berkonsumsi tidak lagi mempertimbangkan fungsi atau kegunaan ketika membeli barang melainkan mempertimbangkan prestise yang melekat pada barang tersebut. Jika perilaku konsumsi tersebut dilakukan secara berlebihan dan berkelanjutan untuk mengejar kepuasan semata tanpa mempertimbangkan aspek mas lbjlahah, maka hal tersebut hanya akan menimbulkan malapetaka bagi diri sendiri maupun orang lain. Gaya hidup hedonisme masuk dalam kehidupan sebagian besar rumah tangga. Paham 
hedonisme berusaha menjelaskan adalah baik apa yang memuaskan keinginan manusia dan apa yang meningkatkan kuantitas kesenangan itu sendiri (K. Bertens, 2000: 235-238).

Budaya masyarakat menuju aktivitas konsumsi dan pengembangan suatu gaya hidup saat ini semakin tinggi dengan semakin majunya industrialisasi melalui proses pembelajaran melalui majalah, koran, buku, televisi, dan radio, yang banyak menekankan peningkatan diri, pengembangan diri, serta bagaimana membangun gaya hidup. Industrialisasi telah membawa masyarakat modern kearah barang-barang konsumsi. Dengan adanya industrialisasi, maka datang ideologi doktrin konsumerisme bahwa diri tidak bisa lengkap tanpa banyak barang-barang dan bahwa tujuan dapat dicapai dan masalah diselesaikan melalui konsumsi yang tepat. Pesan konsumerisme ini yang merajalela dalam masyarakat industri modern, yang berasal dari setiap surat kabar, majalah, televisi, dan billboard (Patricia L. Murphy, 2000: 636).

Gaya hidup hedonis menyebabkan rumah tangga hidup dalam perilaku konsumsi berlebihan. Perilaku tersebut muncul salah satunya karena didorong oleh kemudahan mendapatkan hutang atau kredit. Kemudahan dalam berkonsumsi saat ini dapat terlihat dengan dimilikinya beberapa kartu kredit yang dimiliki oleh beberapa rumah tangga. Kepemilikan kartu kredit akan memicu rumah tangga yang memegangnya untuk membeli barang atau jasa yang diinginkannya walaupun pada saat itu tidak memiliki uang tunai. Perilaku setiap rumah tangga dalam berkonsumsi yang dilakukan di luar batas kemampuan keuangan yang dimiliki pada saat ini. Tetapi, tentunya setiap rumah tangga memiliki rasionalitas alasan, mengapa mereka memutuskan untuk melakukan hal tersebut.

Hasil temuan empiris Betti et al. (2007; 136) menunjukkan bahwa hutang berlebihan merupakan masalah yang signifikan di seluruh negara anggota Uni Eropa di pertengahan 1990-an. Bahwa beberapa faktor utama di balik hutang berlebihan bisa terjadi market failure di pasar kredit. Di samping adanya kendala likuiditas dan kurangnya akses ke pasar kredit formal. Pendapat lain menunjukkan bahwa hutang rumah tangga yang berlebihan berkontribusi pada resesi terburuk dalam beberapa dekade. Penelitian ini meng- 
identifikasi siklus hidup dan sikap kredit sebagai penentu utama yang menggunakan hutang. Rumah tangga muda lebih cenderung untuk meminjam untuk konsumsi, mereka juga percaya bahwa ada hak untuk meminjam untuk membeli barang mewah atau menutup biaya hidup. Selain itu, rumah tangga yang membenarkan pinjaman untuk tujuan konsumsi akan memiliki beban utang konsumen yang lebih tinggi. Kapasitas hutang (atau kredit) dan disiplin keuangan juga faktor penting dalam menentukan penggunaan hutang rumah tangga (Diane K Schooley dan Debra Drecnik Worden, 2010: 266).

Akar penyebab krisis ekonomi adalah konsumsi yang berlebihan disertai dengan rekor tingkat tabungan rendah dan anggaran yang besar dan defisit transaksi berjalan (Gregory W Brown dan Christian Lundblad, 2009: 7). Implikasi negatif dari konsumsi berlebihan adalah konsumsi hedonik domestik yang telah menyebabkan penurunan tajam tabungan nasional. Masalahmasalah ini sebagian besar disebabkan oleh konsumsi berlebihan dan produktivitas yang menurun (Bosworth, Barry P., Lawrence dan Robert Z., 1989: 10 ). Motif konsumsi hedonis dan atau utilitarian mengedepankan nilai konsumsi yang maksimum (B. J. Babin, W. R. Darden, dan M. Griffin, 1994: 644-656). Di Amerika Serikat, adaptasi hedonis mendorong overspending dan hutang. Studi menunjukkan bahwa individu akan menghabiskan lebih sedikit dan memperoleh manfaat lebih hedonis dengan menghilangkan hutang (Joseph Chancellor, dan Sonja Lyubomirsky, 2011: 131-138).

\section{Rasionalitas}

Terminologi rasionalitas merupakan terminologi yang sangat longgar. Argumentasi apapun yang dibangun, selama hal tersebut memenuhi kaidah-kaidah logika yang ada, dan oleh karenanya dapat diterima akal, maka hal tersebut dapat dianggap sebagai bagian dari ekspresi rasionalitas. Oleh karena itu, terminologi rasionalitas dibangun atas dasar kaidah-kaidah yang diterima secara universal dan tidak perlu dilakukan pengujian untuk membuktikan kebenarannya, yang disebut sebagai aksioma. Aksioma-aksioma ini akan diposisikan sebagai acuan dalam pengujian rasionalitas dari suatu argumen 
atau perilaku (P3EI UII-BI, 2008: 27).

Dalam berkonsumsi setiap rumah tangga menganggap diri mereka rasional walaupun ada kemungkinan rumah tangga lain menganggap rumah tangga tersebut tidak rasional. Kondisi ini bisa muncul disebabkan adanya alasan yang dimiliki oleh rumah tangga tersebut yang tidak diketahui oleh orang lain. Sebagai misal: ketika ada rumah tangga saat ini memutuskan mengajukan pinjaman atau pembiayaan di lembaga keuangan tertentu dengan besarnya cicilan sebesar gaji pokok perbulan yang rumah tangga tersebut dapatkan. Jika diperhatikan sekilas, keputusan yang diambil rumah tangga tersebut bisa dianggap tidak rasional. Akan tetapi, rumah tangga tersebut melakukan hal tersebut didasarkan pada ekspektasi pendapatan yang akan diterima, karena akan ada kenaikan pendapatan atau akan menerima tambahan tunjangan setelah lulus sertifikasi, jika profesi individu dalam rumah tangga tersebut seorang guru atau dosen.

Pilihan rasional sebagai model penjelasan dari tindakan-tindakan manusia, dimaksudkan untuk memberikan analisis formal dari pengambilan keputusan rasional berdasarkan sejumlah kepercayaan dan tujuan. Setiap rumah tangga memiliki latar belakang sosial yang besar kemungkinannya berbeda sehingga dalam hal kepercayaan dan tujuan masing-masing rumah tangga akan sesuatu hal termasuk perilaku konsumsinya, kemungkinan besarnya juga berbeda.

Konsistensi prinsip tidak mencukupi untuk mendefinisikan rasionalitas sehingga jika pencapaian tujuan individu tidak menyiratkan konsistensi, patut dipertanyakan apakah perilaku fungsional yang melanggar prinsip konsistensi harus disebut "irasional" (Jörg Rieskamp, Jerome R. Busemeyer, dan Barbara A. Mellers 2006: 631). Perilaku tidak boleh disebut tidak rasional hanya karena gagal untuk menyesuaikan norma-norma rasionalitas penuh dan hanya dibatasi rasionalitas tidak irasionalitas. Bahwa rasionalitas adalah deskripsi akurat terhadap perilaku manusia dengan mempertimbangkan bahwa orang membuat keputusan dengan waktu, pengetahuan, dan perhitungan yang terbatas (Reinhard Selten, 2001: 15). 
Pilihan yang paling rasional bagi tiap rumah tangga tentunya dipercaya memiliki tujuan untuk mencapai kesejahteraan, walaupun sering kali pilihan tersebut menurut orang lain karena keterbatasan waktu, pengetahuan, dan perhitungan bisa dianggap tidak rasional, banyak dialami dalam kehidupan masyarakat. Perilaku konsumsi suatu rumah tangga cukup besar yang disebakan karena beroriantasi pada kehidupan di akhirat dengan cara rumah tangga tersebut (kepala keluarga dan anak-anaknya) selalu berderma, membayar zlakat, infak dan sedekah, bisa dianggap perilaku rumah tangga tersebut tidak rasional bagi orang lain karena keterbatasan waktu, pengetahuan, dan perhitungan.

Rasionalitas dalam Islam tentu berbeda dengan rasionalitas dalam kehidupan dunia barat yang materialistik dan individualistik. Rasionalitas dunia barat atau konvensional cenderung mendeskripsikan sesuatu dianggap rasional jika mengandung keuntungankeuntungan bendawi bagi dirinya. Di samping itu, masing-masing berusaha menggunakan logika mereka untuk meraih keuntungan hidup yang sebesar-besarnya. Dalam Islam, rasionalitas didasarkan pada penggunaan akal yang seluas-luasnya, yaitu dengan mengombinasikan aspek religiusitas yang dapat memperbaiki kehidupannya. Sehingga pencapaian kebahagiaan dan keuntungan hidup tidak hanya untuk kepentingan diri sendiri tetapi juga untuk kemaslahatan masyarakat secara keseluruhan. Di samping itu seorang muslim dalam berkonsumsi tidak hanya mengejar kepuasan semata tetapi konsumsi yang berorientasi untuk mendapatkan mas/bllahah.

\section{Teori Prospek}

Dalam memutuskan sesuatu, individu sering kali dihadapkan pada beberapa alternatif pilihan keputusan dan biasanya didasarkan pada alasan yang berkaitan dengan prospek yang ada. Prospek tersebut disertai dengan keuntungan dan kerugian yang akan ditimbulkan. Barber dan Odean menyatakan bahwa secara sistematis, seseorang bisa menyimpang dari penilaian optimal dan keputusan yang telah ditetapkan (B. Barber dan T. Odean, 1999: 41). Beberapa alternatif pengambilan keputusan individu sebagai risiko, disebut teori prospek (Daniel Kahneman, dan Amos Tversky, 1979: 274). 
Kahneman dan Tversky (1979) dipandang sebagai tokoh pertama yang melontarkan gagasan mengenai perilaku risk-taking (yang kemudian dikenal dengan Prospect Theory) yang merupakan koreksi terhadap Expected Utility Theory (Victor Ricciardi, dan Helen K. Simon, 2000). Munculnya ketidak pastian sering kali sebagai penyebab akan munculnya suatu resiko. Sedangkan preferensi risiko seseorang apakah dia seorang yang risk averse atau risk seeking dapat dilihat pada pilihan yang dibingkai sedemikian rupa atas pilihan tersebut. Disampaikan juga oleh Kahneman dan Tversky, bahwa teori prospek menyatakan bahwa frame yang diadopsi seseorang dapat mempengaruhi keputusannya. Dalam teori prospek, hasil keputusan (outcomes) digambarkan sebagai deviasi positif atau negatif (keuntungan atau kerugian) dari suatu titik referen yang bersifat netral yang ditetapkan nilainya sebesar nol (Daniel Kahneman, dan Amos Tversky, 1979: 286).

Kahneman dan Tversky mengemukakan empat konsep kerangka preferensi resiko individual. Pertama, mental accounting; individu mengevaluasi aset-aset berdasarkan gains dan losses, tidak berdasar kekayaan akhir (final wealth). Kedua, loss aversion; individu cenderung lebih bersikap menghindari resiko dibandingkan mengejar keuntungan. Ketiga, asymmetric risk preference; individu cenderung risk-seeking dalam domain losses dan bersikap risk averse dalam domain gains. Keempat, probability weighting function; individu mengevaluasi probabilitas-probabilitas ekstrim dengan cara meng-overestimate probabilitas rendah dan meng-underestimate yang tinggi (Jose Luiz Barros Fernandes, Juan Ignacio Pena dan Benjamin Miranda Tabak, 2006).

Dalam pengambilan keputusan yang dilatarbelakangi suatu kondisi ketidakpastian seringkali akan menimbulkan beberapa resiko di samping target yang akan dicapai. Oleh karena itu sering kali pengambilan keputusan yang dilakukan oleh seorang individu dianggap rasional bagi individu tersebut yang dilatarbelakangi suatu prospek tertentu tetapi tidak rasional bagi individu-individu yang lain jika kurang memahami secara mendalam atas prospek yang ada dan hanya memandang kemungkinan resiko yang akan ditimbulkannya. 
Dalam hal perilaku konsumsi yang cukup berlebihan dilakukan oleh seorang individu yang dilatarbelakangi suatu prospek, akan dianggap rasional bagi individu tersebut, akan tetapi bisa dianggap tidak rasional bagi individu-individu yang lain. Konsumsi yang sekilas terlihat berlebihan bisa dilatarbelakangi oleh asumsi bahwa konsumsi tersebut sudah dipersiapkan sebelumnya yang didanai dari tabungan, atau bahwa konsumsi tersebut didanai dari pinjaman yang karena adanya ekspektasi pendapatan yang dimiliki oleh individu tersebut.

\section{Religiusitas dan Konsumsi Islam}

Menurut Glock dan Stark (1965: 20-21), ada lima dimensi keberagamaan, yaitu idiologis, ritualistik, eksperiensial, konsekuensial, dan intelektual. Sedangkan menurut Ancok dan Suroso (2008: 8081), dimensi keyakinan dapat disejajarkan dengan akidah, dimensi peribadatan atau praktik agama disejajarkan dengan syariah, dimensi pengalaman atau penghayatan disejajarkan dengan ihsan, dimensi pengetahuan agama disejajarkan dengan ilmu, dan dimensi pengamalan disejajarkan dengan akhlak. Kelima dimensi religiusitas tiap individu kemungkinan besar tingkatannya berbeda, sehingga wujudnya dalam berbagai sisi kehidupan juga berbeda, termasuk dalam hal ini aktivitas ekonomi pada umumnya dan konsumsi pada khususnya. Sehingga perbedaan religiusitas tiap individu ini berpotensi menyebabkan perbedaan dalam berkonsumsi baik barang maupun jasa, baik dalam segi jumlah maupun jenis barang atau jasa yang dikonsumsikannya.

Berdasarkan hal tersebut di atas menunjukkan, bahwa tingkat religiusitas tiap individu berpengaruh terhadap tingkat konsumsi. Hal ini dapat dirumuskan dalam fungsi persamaan:

$$
C=f(R)
$$

Dimana :
C: Konsumsi
R: Religiusitas

Pemikiran tersebut di atas didasarkan pada pemahaman, bahwa individu yang religiusnya tinggi, maka individu tersebut me- 
mahami akan adanya keberadaan mas'hllahah. Dalam berkonsumsi barang atau jasa, seorang konsumen memperoleh kepuasan dan atau mas/hllahah. Mas/bllahah munculnya mungkin tidak seketika dapat dirasakan oleh konsumen. Hal ini karena dalam mas'bllahah terkandung dua hal yaitu mas 'blahah fisik atau material dan berkah (P3EI UII-BI, 2008: 142-143). Tingkatan religiusitas tiap individu menyebabkan pemahaman akan keberadaan mas lh llahah atas barang atau jasa yang dikonsumsikannya kemungkinan besar juga berbeda.

Dalam teorinya, Keynes menyebutkan bahwa konsumsi saat ini dipengaruhi oleh pendapatan saat ini. Dalam berkonsumsi yang dikaitan dengan pendapatan, Islam juga mengajarkannya. Hal ini dapat dilihat dalam al-Qur'an yang bunyinya:

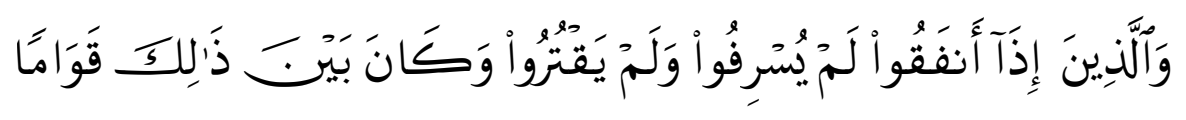

"Dan orang-orang yang apabila membelanjakan (harta), mereka tidak berlebihan, dan tidak (pula) kikir, dan adalah (pembelanjaan itu) di tengah-tengah antara yang demikian" (QS, 25: 67).

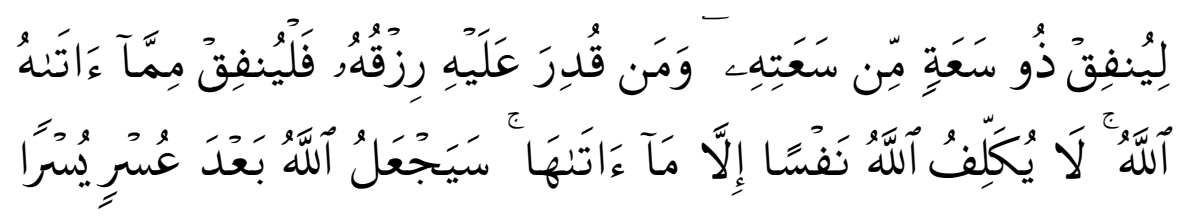

"Hendaklah orang yang mampu memberi nafkah menurut kemampuannya. dan orang yang disempitkan rezkinya hendaklah memberi nafkah dari harta yang diberikan Allah kepadanya. Allah tidak memikulkan beban kepada seseorang melainkan sekedar apa yang Allah berikan kepadanya. Allah kelak akan memberikan kelapangan sesudah kesempitan" (QS, al-Thalaaq: 7).

Kedua ayat tersebut di atas menggambarkan bahwa seorang muslim dalam berkonsumsi hendaknya tidak melampaui batas kemampuan (pendapatan dan atau kekayaan yang dimiliki) tetapi juga tidak terlalu kikir. Jika dalam berkonsumsi itu melampaui batas kemampuan, akan berimplikasi pada naiknya sisi permintaan. Kenaikan permintaan jika tidak diimbangi dengan kenaikan penawaran maka akan menimbulkan kenaikan harga. Dan jika ini diimbangi dengan kenaikan penawaran yang dibarengi dengan 
pengeksploitasian sumberdaya alam yang berlebihan, hal tersebut tentunya akan merusak keseimbangan ekosistem alam.

Oleh karena itu dalam berkonsumsi umat Islam diajarkan untuk tidak melampaui batas kemampuan atau pendapatan yang dimiliki. Berdasarkan hal tersebut, Islam mengajarkan pada umatnya dalam berkonsumsi harus mempertimbangkan pendapatannya. Hal ini jika dijabarkan dalam sebuah fungsi akan menjadi:

$$
\mathrm{C}=\mathrm{f}(\mathrm{Y})
$$

Sehingga seorang muslim harus berusaha mempertahankan pola konsumsinya supaya tidak dimasukkan dalam perilaku konsumsi yang berlebihan. Maka konsumsi periode sekarang harus tidak melebihi pendapatan periode sekarang. Sehingga besarnya APC (konsumsi rata-rata) nilainya tidak melebihi dari 1. Besarnya APC dapat diperoleh dari:

$$
A P C=\frac{C}{Y}
$$

Islam memiliki pandangan tersendiri berkaitan dengan alokasi dari pendapatan. Pembuatan keputusan konsumsi dalam ekonomi Islam tidak seperti fungsi yang ditunjukkan model Keynesian. Hal penting, dalam ekonomi Islam, adalah mengetahui terlebih dahulu tentang bagaimana distribusi penghasilan dan kekayaan yang akan berimplikasi pada tabungan dan pertumbuhan ekonomi. Pengeluaran bagi orang lain di jalan Allah adalah bagian dari perilaku konsumsi yang didorong oleh diri-sendiri sama seperti pengeluaran untuk pribadi individu.

\section{Metode Penelitian}

\section{Obyek Penelitian}

Dalam penelitian ini yang menjadi obyek penelitian adalah rumah tangga konsumen muslim yang sudah hidup mandiri dan mempunyai pendapatan sendiri tetapi yang belum mendapatkan atau menerima kekayaan (warisan/hibah) dari orang tuanya dan mereka tersebut tinggal di Daerah Istimewa Yogyakarta (DIY). 


\section{Desain Penelitian}

Desain penelitian yang digunakan dalam penelitian ini merupakan desain metode survey. Menggunakan kuesioner dan wawancara.

\section{Sampel Penelitian}

Pengambilan sampel dalam penelitian ini dilakukan berdasarkan kriteria dan beberapa karakteristik sampel yang sudah ditentukan sebelumnya (rumah tangga muslim yang sudah hidup mandiri dan mempunyai pendapatan sendiri tetapi belum menerima atau mendapatkan kekayaan dari orang tuanya) yang disesuaikan sesuai dengan tujuan dan maksud penelitian.

\section{Alat Analisis}

Analisis yang digunakan merupakan analisis diskriptif dan kuantitatif. Untuk melihat sejauh mana tingkat konsumsi dengan melihat nilai APC (average propencity to consume). Sedangkan untuk melihat seberapa tingkat religiusitasnya dengan melihat nilai rata-rata skor yang diperoleh.

\section{Analisis Data}

\section{Kecenderungan Konsumsi}

Perilaku konsumsi yang tergolong isra $>$ fmerupakan perilaku yang merugikan baik bagi dirinya maupun orang lain. Kerugian bagi dirinya antara lain tambahan konsumsi yang rumah tangga lakukan, yaitu tambahan mas/bllahah (manfaat) yang dia terima sudah tidak signifikan dengan pengorbanan yang dilakukan. Kecenderungan rumah tangga dalam konsumsinya dikatakan isra $>f$ besar kemungkinannya disebabkan karena mengejar kepuasannya saja, tanpa didasarkan pada masłbllahah.

Konsumsi berlebihan pada saat nilai dikatakan isra $>f$ bila nilai APC lebih besar dari satu, jika diwujudkan dalam persamaan matematika: $\mathrm{C} / \mathrm{Y}$ e" 1 . Berdasarkan persamaan tersebut dan data besarnya konsumsi dan pendapatan (suami dan istri) secara ratarata dapat diperoleh sebagai berikut: 


$$
\frac{3005275,23}{4221009,17}=0,71198026
$$

Hasil perhitungan tersebut di atas menunjukkan bahwa nilai APC lebih kecil dari satu $(0,71198026<1)$, sehingga perilaku konsumsi muslim belum dikategorikan berlebihan. Oleh karena itu seorang muslim dalam berkonsumsi selalu berusaha secara proporsional atau di tengah-tengah yaitu tidak berlebihan atau boros tetapi juga tidak kikir.

Islam mengajarkan umatnya untuk hidup secara proporsional, yaitu hidup sesuai kemampuannya yaitu tidak berlebihan, tidak boros, bermewah-mewahan dan tidak terlalu kikir. Dengan kata lain dapat diambil prinsip konsumsi yaitu sepadan yaitu tidak besarpasak dari pada tiang. Hal ini berkorelasi dengan ayat berikut:

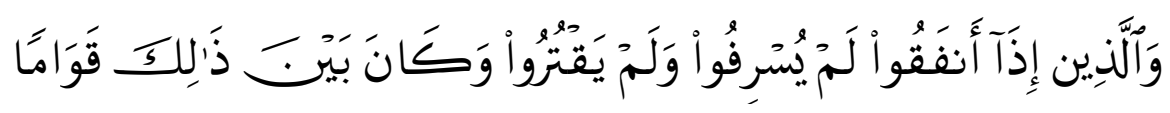

"Dan orang-orang yang apabila membelanjakan (harta), mereka tidak berlebihan, dan tidak (pula) kikir, dan adalah (pembelanjaan itu) di tengah-tengah antara yang demikian" (Qs, al-Furqaan: 67).

Hidup berlebihan dapat berupa hidup yang melebihi batas kesederhanaan yang dihalalkan oleh Allah. Berdasarkan hal tersebut, Islam mengajarkan pada setiap muslim untuk hidup secara proporsional.

\section{Religiusitas}

Hasil temuan menunjukkan nilai rata-rata tingkat religiusitas rumah tangga muslim berdasarkan lima dimensi keberagamaan, sebagai berikut:

Tabel 1. Tingkat Religiusitas Responden

\begin{tabular}{|c|c|c|c|c|c|c|c|c|c|c|}
\hline \multirow[t]{2}{*}{ Keterangan } & \multicolumn{2}{|c|}{$\begin{array}{l}\text { Sangat } \\
\text { Religius }\end{array}$} & \multicolumn{2}{|c|}{ Religius } & \multicolumn{2}{|c|}{$\begin{array}{l}\text { Cukup } \\
\text { Religius } \\
\end{array}$} & \multicolumn{2}{|c|}{$\begin{array}{c}\text { Tidak } \\
\text { Religius } \\
\end{array}$} & \multicolumn{2}{|c|}{$\begin{array}{c}\text { Sangat Tidak } \\
\text { Religius }\end{array}$} \\
\hline & $?$ & $\%$ & $?$ & $\%$ & $?$ & $\%$ & $?$ & $\%$ & $?$ & $\%$ \\
\hline Idiologis & 85 & 77,98 & 22 & 20,18 & 2 & 1,83 & 0 & 0 & 0 & 0 \\
\hline Ritualistik & 23 & 21,10 & 55 & 50,46 & 26 & 23,8 & 2 & 1,83 & 3 & 2,75 \\
\hline Eksperiensial & 41 & 37,61 & 65 & 59,63 & 2 & 1,83 & 1 & 0,91 & 0 & 0 \\
\hline Intelektual & 76 & 69,72 & 32 & 29,36 & 1 & 0,91 & 0 & 0 & 0 & 0 \\
\hline Konsekuensial & 53 & 48,62 & 56 & 51,38 & 0 & 0 & 0 & 0 & 0 & 0 \\
\hline $\begin{array}{l}\text { Religiusitas Secara } \\
\text { Keseluruhan }\end{array}$ & 41 & 37,61 & 66 & 60,55 & 2 & 1,835 & 0 & 0 & 0 & 0 \\
\hline
\end{tabular}

Sumber: Data terolah 
Berdasarkan hasil survai tersebut di atas menunjukkan, bahwa dari skala 0 sampai dengan 10, tingkat religiusitas secara keseluruhan responden berkisar pada skala 5 dan 6 (cukup religius) sebesar 1,83\%, skala 7 dan 8 (Religius) sebesar 60\%, skala 9 dan 10 (sangat religius) sebesar 37,61\%. Jadi responden dominan memiliki tingkat religiusitas yang tinggi. Tingginya religiusitas dapat sebagai pengendali perilaku konsumsi, sehingga perilaku konsumsinya berdasarkan rasionalitas seorang muslim, yaitu tidak berlebihan.

Perilaku konsumsi rumah tangga tersebut didasarkan pada rasionalitas (P3EI UII-BI, 2008: 27). Rasionalitas inilah yang mendorong munculnya ekspektasi, kemudian ekspektasi inilah yang memotivasi perilaku konsumsi rumah tangga tersebut. Ekspektasi seorang muslim dalam perilaku hidupnya di antaranya bisa mendapatkan pahala dari Allah swt., demikian pula perilaku mereka dalam berkonsumsi. Dasar rasionalitas seorang muslim dalam berkonsumsi tidak hanya untuk kepentingan diri sendiri akan tetapi juga berkonsumsi untuk kepentingan orang lain (zakat, infak dan sedekah) karena menginginkan atau mengharapkan adanya pahala yang melimpah di samping tidak ingin disebut kikir. Rasionalitas ini dipengaruhi oleh faktor religiusitas masing-masing individu.

Rasionalitas seorang muslim dalam berkonsumsi berbeda dengan rasionalitas bukan muslim. Seorang konsumen muslim tidak hanya mencapai kepuasan dari konsumsi barang dan penguasaan barang tahan lama, akan tetapi juga dari konsumsi untuk memenuhi kebutuhan orang lain (sedekah).

Semakin tinggi religiusitas seseorang maka akan semakin besar konsumsinya, karena konsumsi seorang muslim terkandung di dalamnya termasuk pengeluaran untuk sedekah. Hal ini disebabkan seorang muslim dalam berkonsumsinya akan mengikuti ajaranajaran yang disampaikan dalam ajaran agamanya. Dalam berkonsumsi atau membelanjakan hartanya, al-Qur'an mengajarkan seorang muslim dalam berkonsumsi tidak hanya untuk memenuhi kebutuhan sendiri tetapi juga untuk kebutuhan orang lain. Hal ini berkorelasi dengan ayat sebagai berikut: 


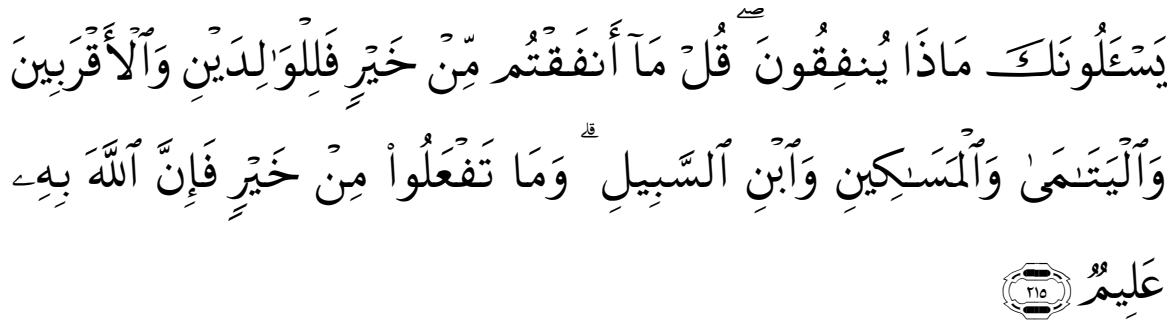

"Mereka bertanya tentang apa yang mereka nafkahkan. Jawablah: "Apa saja harta yang kamu nafkahkan hendaklah diberikan kepada ibu-bapak, kaum kerabat, anak-anak yatim, orang-orang miskin dan orang-orang yang sedang dalam perjalanan." Dan apa saja kebaikan yang kamu buat, maka sesungguhnya Allah Maha mengetahuinya" (Qs, al-Baqarah: 215).
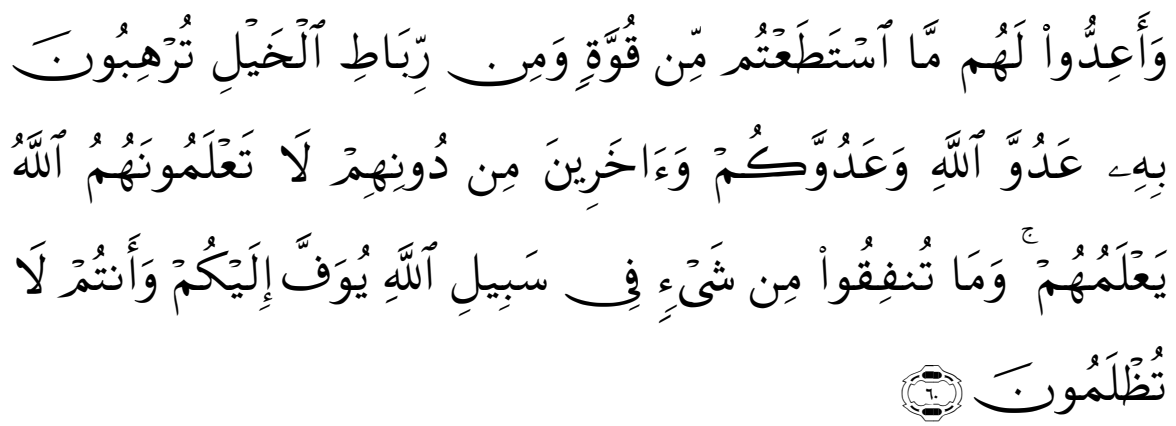

"Dan siapkanlah untuk menghadapi mereka kekuatan apa saja yang kamu sanggupi dan dari kuda-kuda yang ditambat untuk berperang (yang dengan persiapan itu) kamu menggentarkan musuh Allah dan musuhmu dan orang orang selain mereka yang kamu tidak mengetahuinya; sedang Allah mengetahuinya. Apa saja yang kamu nafkabkan pada jalan Allab niscaya akan dibalasi dengan cukup kepadamu dan kamu tidak akan dianiaya (dirugikan)" (Qs, al-Anfaal: 60).

Berdasarkan dua ayat tersebut di atas, seorang muslim dalam mengalokasikan pendapatan atau harta kekayaan yang dimiliki atau diperolehnya akan digunakan untuk berkonsumsi. Akan tetapi tidak hanya untuk kebutuhan sendiri melainkan juga untuk kebutuhan orang lain atau komunitas yang membutuhkan pertolongan dalam rangka untuk mendapatkan masłblahah. Dimana mas/bllahah meliputi mas/bllahah fisik dan berkah. Mas/hllahah 
fisik dalam rangka untuk pemenuhan kebutuhan duniawi, sebagai pemenuhan kebutuhan dasar.

Perilaku konsumsi muslim yang semakin religius maka akan semakin besar konsumsinya (konsumsi berupa sedekah). Hal ini juga berkorelasi dengan ayat:

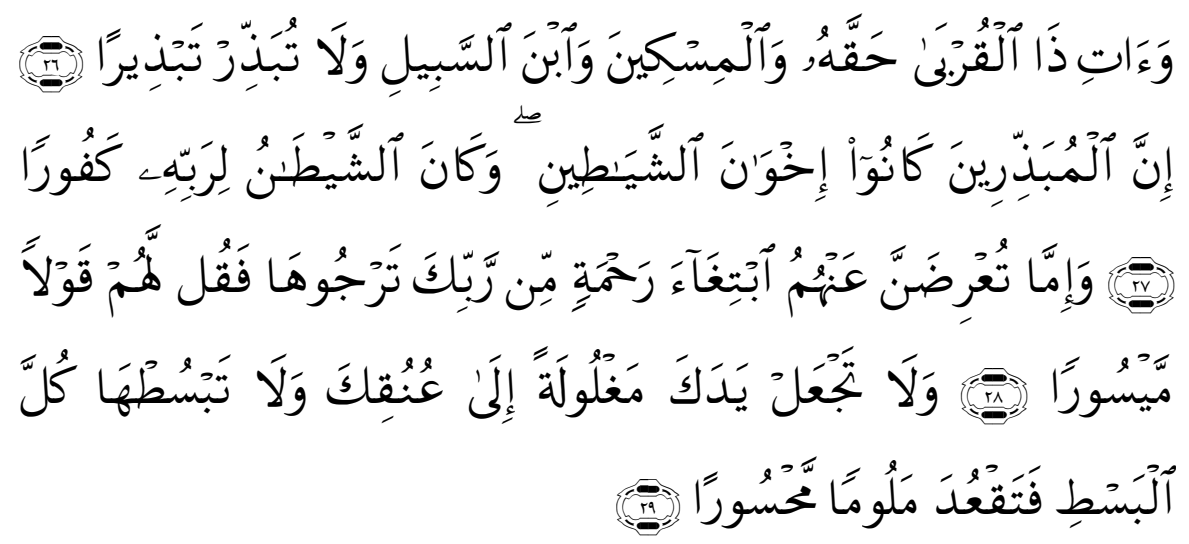

"Dan berikanlah kepada keluarga-keluarga yang dekat akan haknya, kepada orang miskin dan orang yang dalam perjalanan dan janganlah kamu menghambur-hamburkan (hartamu) secara boros".

"Sesungguhnya pemboros-pemboros itu adalah saudara-saudara syaitan dan syaitan itu adalah sangat ingkar kepada Tuhannya".

"Dan jika kamu berpaling dari mereka untuk memperoleh rahmat dari Tuhanmu yang kamu harapkan, maka katakanlah kepada mereka ucapan yang pantas".

"Dan janganlah kamu jadikan tanganmu terbelenggu pada lehermu dan janganlah kamu terlalu mengulurkannya. Karena itu kamu menjadi tercela dan menyesal" (Qs, al-Israa': 26-29).

Keempat ayat di atas memiliki korelasi dengan hasil penelitian ini, bahwa secara garis besar perilaku konsumsi muslim, pertama, merupakan suatu kebajikan memberikan hal jaminan hidup yaitu pemenuhan kebutuhan primer kepada keluarga, kerabat, orang miskin dan ibn sabil. Kedua, tidak bersikap boros, karena sikap boros merpakan perilaku syaitan. Ketiga, tidak bersikap kikir dan juga tidak melebihi batas kemampuan dalam berinfak.

Dengan demikian dari keempat ayat di atas dapat diambil prinsip konsumsi yaitu mendukung pemenuban kebutuban primer 
keluarga, kerabat, miskin dan ibn sabil, dan tidak boros lagi tidak kikir melainkan sesuai kemampuan. Ayat ini mempertegas gambaran perilaku seorang muslim yang memiliki religiusitas, bahwa perilaku pengeluaran konsumsinya saat ini tidak melebihi pendapatan yang dimiliki saat ini. Jadi perilaku konsumsi muslim didorong oleh religiusitas yang menyebabkan perilaku konsumsinya tidak ingin disebut kikir tetapi juga tidak berlebihan.

Dengan masuknya aspek religiusitas pada diri seseorang, dalam rangka pemenuhan kebutuhan dasarnya, yaitu tidak hanya untuk kebutuhan sendiri saja tetapi juga untuk kebutuhan sosial. Kebutuhan sosial ini dapat diaplikasikan dalam bentuk sedekah, infak dan zakat. Perilaku seperti ini akan menciptakan pemerataan pendapatan atau kesejahteraan kepada orang-orang yang membutuhkan, di samping itu tujuan menyisihkan sebagian harta atau pendapatannya kepada yang membutuhkan dapat menciptakan sebuah masyarakat yang kuat dan dapat pula digunakan untuk menyucikan harta atau pendapatan dari kemungkinan s/bjubhat.

\section{Prospek}

Prospek yang dimiliki oleh rumahtangga muslim tersebut dalam berkonsumsi adalah ingin mendapatkan mas $/$ hlahah. Hal tersebut dapat dilihat dari rata-rata tingkat religiusitas yang tinggi. Prospek seorang muslim dalam perilaku konsumsinya tidak hanya kehidupan duniawi akan tetapi juga kehidupan di akhirat. Hal tersebut berkorelasi dengan ayat sebagai berikut:

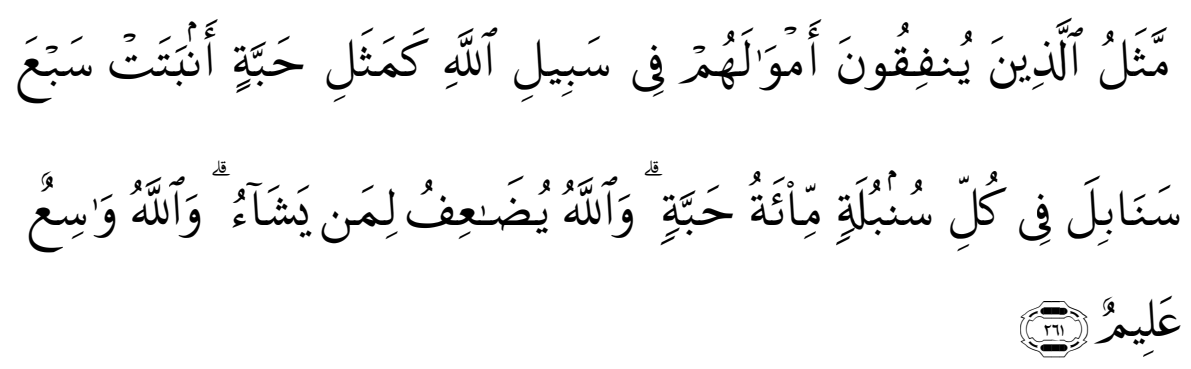

"Perumpamaan (nafkah yang dikeluarkan oleh) orang-orang yang menafkahkan hartanya di jalan Allah adalah serupa dengan sebutir benih yang menumbuhkan tujuh bulir, pada tiap-tiap bulir seratus biji. Allah melipat gandakan (ganjaran) bagi siapa yang dia ke- 
hendaki. dan Allah Maha luas (karunia-Nya) lagi Maha Mengetahui" (Qs, al-Baqarah: 261).

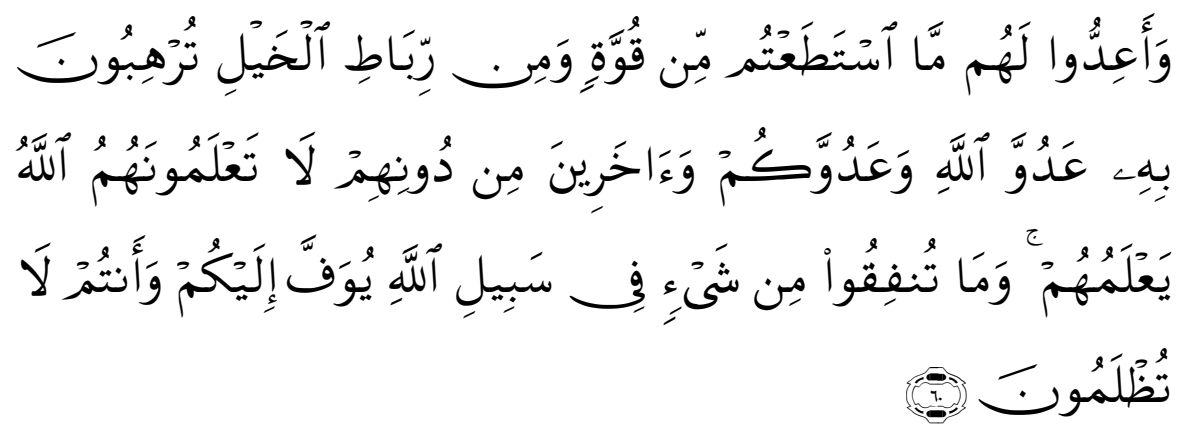

"Dan siapkanlah untuk menghadapi mereka kekuatan apa saja yang kamu sanggupi dan dari kuda-kuda yang ditambat untuk berperang (yang dengan persiapan itu) kamu menggentarkan musuh Allah dan musuhmu dan orang orang selain mereka yang kamu tidak mengetahuinya; sedang Allah mengetahuinya. Apa saja yang kamu nafkabkan pada jalan Allab niscaya akan dibalasi dengan cukup kepadamu dan kamu tidak akan dianiaya (dirugikan)" (Qs. al-Anfaal: 60).

Bagi seorang muslim yang memiliki religiusitas semakin tinggi, maka dia akan semakin mempertimbangkan prospek ke depan dengan lebih baik, termasuk dalam hal ini kehidupan di dunia dan akhirat atas balasan perilakunya. Oleh karenanya, pengeluaran konsumsi seorang muslim dalam bentuk untuk memenuhi kebutuhan orang lain (sedekah) merupakan investasi yang memiliki daya pikat yang tinggi. Daya pikat tersebut bisa dipetik dalam kehidupan di dunia maupun akhirat. Seorang muslim percaya bahwa investasi dalam bentuk sedekah ini akan memberikan prospek keberuntungan dan berkah. Keberuntungan bisa berupa pahala maupun hikmah yang akan dipetik dari perbuatan baik yang dilakukan dalam menafkahkan hartanya. Hal ini berkorelasi dengan ayat sebagai berikut:

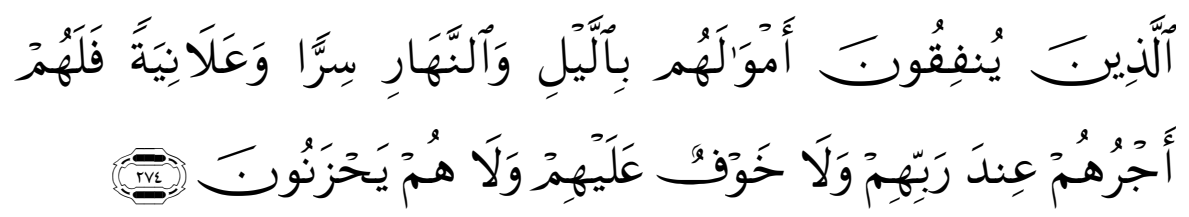


"Orang-orang yang menafkahkan hartanya di malam dan di siang hari secara tersembunyi dan terang-terangan, maka mereka mendapat pahala di sisi Tuhannya. Tidak ada kekhawatiran terhadap mereka dan tidak (pula) mereka bersedih hati" (Qs, al-Baqarah: 274).

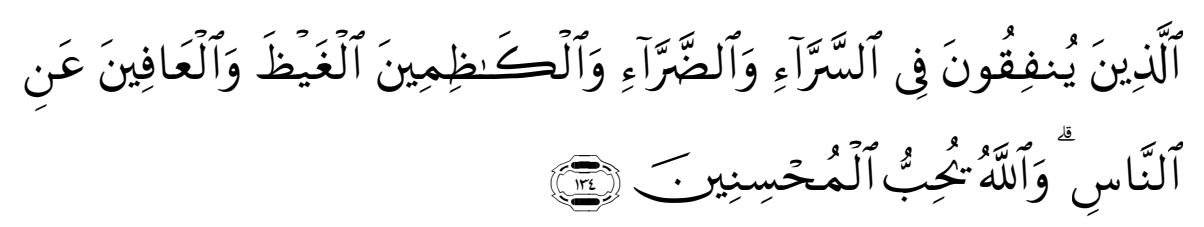

"(yaitu) orang-orang yang menafkahkan (hartanya), baik di waktu lapang maupun sempit, dan orang-orang yang menahan amarahnya dan mema'afkan (kesalahan) orang. Allah menyukai orang-orang yang berbuat kebajikan" (Qs, al-Ali 'Imran: 134).

Perilaku konsumsinya yang menafkahkan hartanya di jalan Allah adalah sebuah perilaku yang terpuji. Apalagi jika perilaku itu dilakukan baik dalam keadaan lapang maupun sempit ataupun dalam segala situasi. Atas perilaku kebajikan tersebut, Allah akan membalasnya dengan cukup. Balasan dari Allah bisa berupa pahala maupun keberuntungan. Keberuntungan yang diperolehnya dapat berupa keberuntungan yang tidak terduga atau dalam bentuk hikmah lain atas perbuatan baik (sedekah) yang dilakukan, sehingga kepuasan marginal seorang muslim dalam pengeluaran konsumsi untuk sedekah adalah tetap.

Jadi semakin religius seseorang, maka memiliki potensi semakin besar tingkat konsumsinya, yang disebabkan semakin besar daya pikat yang akan diberikan dalam pengeluaran konsumsi untuk sedekah. Akan tetapi tingkat konsumsinya masih tetap proporsional dengan mempertimbangkan pendapatan yang dimiliki, sehingga konsumsinyapun masih tetap tidak berlebihan yang ditunjukkan nilai APC $<1$.

\section{Kesimpulan}

Hasil penelitian ini menunjukkan bahwa perilaku konsumsi yang dilakukan oleh individu rumah tangga yang menjadi responden penelitian, tergolong proporsional yaitu tidak isra $>f$ (berlebihan) tetapi juga tidak kikir. Seorang muslim percaya bahwa pengeluaran konsumsi dalam bentuk sedekah, merupakan investasi yang akan 
memberikan prospek keberuntungan dan berkah. Akan tetapi perilaku konsumsi mereka baik untuk kepentingan diri sendiri maupun untuk memenuhi kebutuhan orang lain, selalu mendasarkan pertimbangan rasionalitas karena adanya moderating religiusitas, sehingga pengeluaran total (konsumsi) mereka tidak melebihi pendapatan total sekarang atau APC $<1$.

\section{Daftar Pustaka}

Ancok, Djamaludin, dan Suroso. 2008. Fuat Nashori, Psikologi Islami: Solusi Islam atas Problem-problem Psikologi, Cet.VII, Yogyakarta: Pustaka Pelajar.

Babin, B. J., Darden,W. R., and Griffin, M.. 1994. "Work and/or Fun: Measuring Hedonic and Utilitarian Shopping Value", Journal of Consumer Research, Vol. 20.

Bagus, Lorens. 2000. Kamus Filsafat, Jakarta: Gramedia.

Barber, B. and Odean, T.. 1999. "The Courage of Misguided Convictions," dalam Financial Analysts Journal, No. 55.

Barry, P., Bosworth, Robert Z Lawrence. 1988/1989. "America In The World Economy", The Brookings Review, Vol. 7, Ed. 1, Winter.

Bertens, K., Etika. 2000. Jakarta: Gramedia.

Betti, G., et al.. 2007. "Consumer Over-indebtedness in the EU: Measurement and Characteristics", Journal of Economic Studies, Vol. 34, Ed. 2.

Brown, Gregory W., and Lundblad,Christian. 2009. "The U.S. Economic Crisis: Root Causes and the Road to Recovery, Journal of Accountancy, Vol. 208, Ed. 4, Oktober.

Fernandes, Jose Luiz Barros, Pena, Juan Ignacio, and Tabak, Benjamin Miranda. 2006. "Behavior Finance adn Estimation Risk in Stockastic Portofolio Optimization," makalah pada Financial Management Association International European Conference di Stockholm.

Glock, C.Y. and Stark, R.. 1965. Religion and Society in Tension, Rand McNally.

Joseph, C., Sonja, L.. 2011. "Happiness and Thrift: When (spending) Less is (hedonically) More", Journal of Consumer Psychology (Elsevier Science), Vol. 21, Issue 2, April. 
Kahneman, Daniel and Tversky, Amos. 1979. "Prospect Theory: An Analysis of Decision under Risk", Econometrica, Vol. 47, No. 2, Maret.

Lutz, Sandy. 2008. "What Do Consumers Want?", Journal of Healthcare Management, Mar/Apr.

Magnis, Franz. 1987. Etika Dasar; Masalah-masalah Pokok Filsafat Moral. Terj. Suseno, Yogyakarta: Kanisius.

Murphy, Patricia, L.. 2000. "The Commodified Self in Consumer Culture: A Cross-Cultural Perspective", The Journal of Social Psychology, Vol. 140, No. 5.

P3EI UII-BI. 2008. Ekonomi Islam, Ed.1, Jakarta: PT. RajaGrafindo Persada.

Reinhard, Selten. 2001. What Is Bounded Rationality? In Bounded Rationality: The AdaptiveToolbox, ed. Gerd Gigerenzer and Reinhard Selten. Cambridge: MIT Press.

Ricciardi, Victor, and Simon, Helen K.. 2000. "What Is Behavioral Finance?" dalam Business, Education and Technology Journal, Fall.

Rieskamp, Jörg, R. Busemeyer, Jerome and A. Mellers, Barbara. 2006. "Extending the Bounds of Rationality: Evidence and Theories of Preferential Choice", Journal of Economic Literature Vol. XLIV, September.

Schooley, D., K., and Worden, D., D.. 2010. "Fueling the Credit Crisis: Who Uses Consumer Credit and What Drives Debt Burden?", Business Economics, Vol. 45, Ed. 4, Oktober.

Stearns, Peter. 2001. Consumerism in World History: The Global Transformation of Desire, London: Routledge.

Stevenson, Nick. 2002. "Consumer Culture, Ecology and the Possibility of Cosmopolitan Citizenship", Consumption, Markets and Culture, Vol. 5, No. 4. 